\title{
Performance Development of a BLDC Motor Driven Water Pump using KY Converter
}

\author{
Anu Priya, Sasilatha \\ Research Scholar, Department of Electrical Engineering (EEEM), AMET University, Chennai, India
}

\begin{tabular}{l}
\hline \hline Article Info \\
\hline Article history: \\
Received Nov 21, 2017 \\
Revised Jan 29, 2018 \\
Accepted Feb 17, 2018 \\
\hline
\end{tabular}

\section{Keywords:}

BLDC motor

KY converter

Perturb \& observe

Solar panel

\begin{abstract}
This paper presents a performance investigation of bldc motor employing $\mathrm{KY}$ converter. Conventional The landsman converter is used to minimize the ripples but the inverter produces high output power ripples, which in turn affect the output of the inverter in The proposed KY converter reduces ripples and smooth dc supply gives to the inverter then it will used to operate brushless dc motor, which inturn improves the motor performance. the electronically commutated brushless DC with voltage source inverter can be operated at fundamental frequency is to reduce switching losses which output in higher efficiency
\end{abstract}

Copyright (C) 2018 Institute of Advanced Engineering and Science. All rights reserved.

\section{Corresponding Author:}

Anu Priya,

Department of Electrical Engineering (EEEM),

AMET University, Chennai, India.

\section{INTRODUCTION}

The Brushless DC (BLDC) motor is the best choice for applications that require high efficiency, high reliability, and high power-to-volume ratio [1]. The Brushless DC motors are called electronically commutated motors, that are battery-powered by a DC electrical supply via an integrated electrical converter power offer [2], that produces AC electrical power to drive the motor. in contrast to DC motors they do not have brushes or switch segments [3]. Thus these motors have terribly low wear and tear, therefore requiring less maintenance [4].

\section{BACKGROUND}

Brushless DC motors uses either internal or external position sensors so as to sense the position of the rotor. In line with the position of rotor the windings within the stator coil ar excited with the assistance of voltage supply electrical converter [5].

\section{THE PROBLEM}

BLDC motor is a high performance motor that is capable of providing large amounts of torque over a extensive speed range.In this paper described that the PV inverter topology it is a high efficiency topology [6]. Firefly algorithm is presented in this paper in this algorithm used to generate the reactive power [7].

\section{PROPOSED SOLUTION}

The circumstance of soalr panel convert sun radiations into electricity without mechanical mechanism, the particle theory of irradiated energy, is called "pv array".solar radiation has pocket of photons [8-9]. Radiation has irregular relationship between temperature and resistance it cause varied output potency to take care of constant output power most electric outlet following technique is employed. the solar cell isn't a vigorous device. It produces neither a 
current nor a voltage. A electrical device cell essential is a p-n semiconductor junction. once exposed to the sunshine, a current is generated (DC current). The generated current modification linearly with the star irradiance [10].

The most normally used MPPT algorithmic program is $\mathrm{P} \& \mathrm{O}$ technique. This algorithmic program uses straightforward feedbackarrangement and tiny measured parameters. During this approach, the module voltage is sporadicallygiven a perturbation and therefore the corresponding output power is compared therewith at the previousperturbing cycle. During this algorithmic program a small perturbation is introduce to the system. Thisperturbation causes the facility of the star module varied. Perturbation reverses as shown in Figure 1.

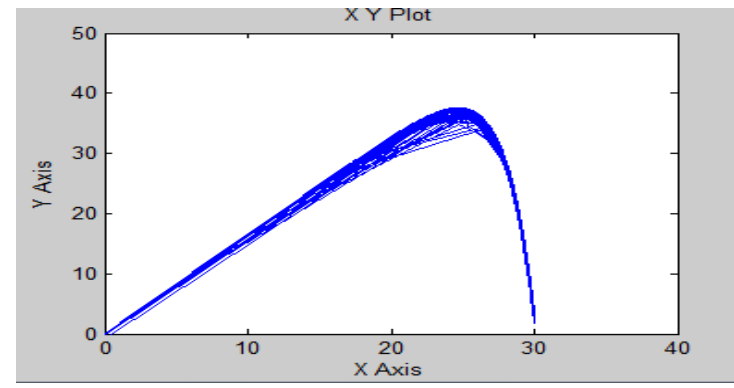

Figure 1. Graph Power versus Voltage for Perturb and Observe Algorithm

\section{PROPOSED SYSTEM DESIGN}

The proposed converter system is designed based on the selection of pump and motor. The $280 \mathrm{w}$ and 7.3 amps $1200 \mathrm{rpm}$ power rating is selected for BLDC motor.

\section{a) KY Converter}

This KY converter is used to reduce ripples in low power applications. It is a buck/ boost converter. It has the efficiency it possesses fast load transient responses. It operates on low output ripples by varying the duty cycle. It steps up the input voltage. It operates at on the non pulsating mode and produces the positive output voltage.

\section{b) Circuit Diagram}

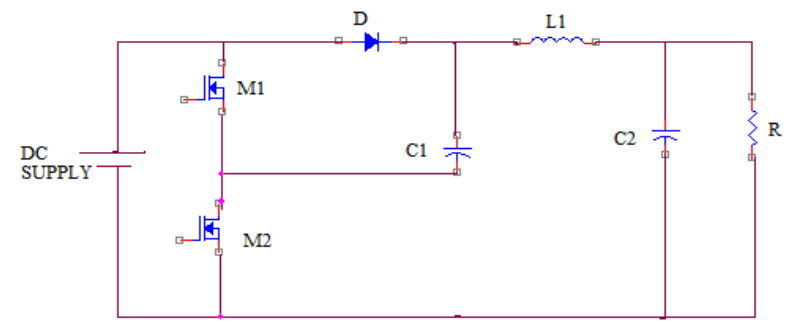

Figure 2. Circuit Diagram of KY converter

\section{BLOCK DIAGRAM} bldc motor

Block diagram of this paper consists of solar panel, ky converter, mppt controller, voltage source inverter and

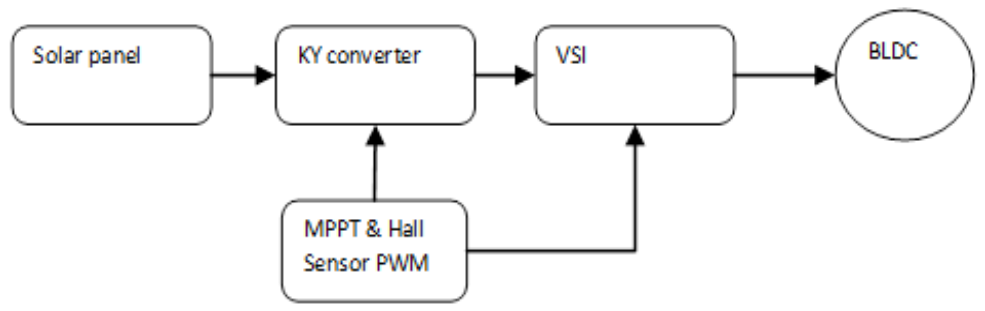

Figure 3. Block diagram of Proposed System 
KY converter reduces the dc ripples it gives smooth dc voltage and output given to voltage source inverter. Voltage supply inverter convert dc into ac. Finally bldc motor running at constant speed.

\section{SIMULATION AND RESULTS}

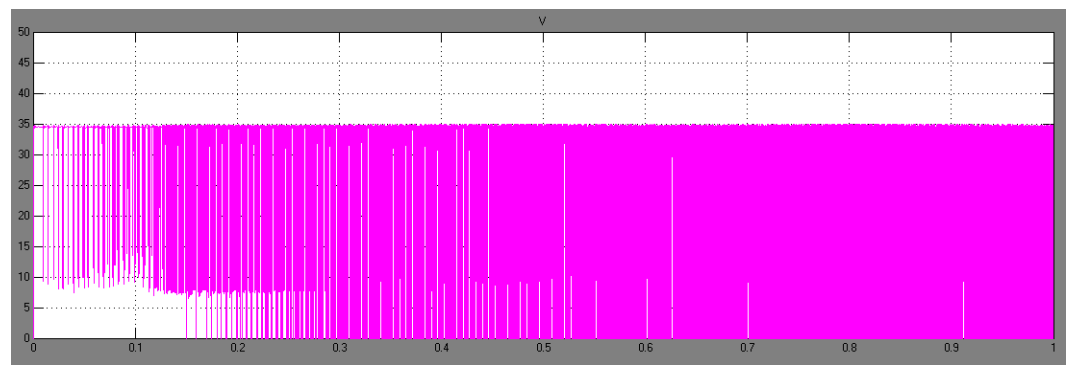

Figure 4. Solar voltages

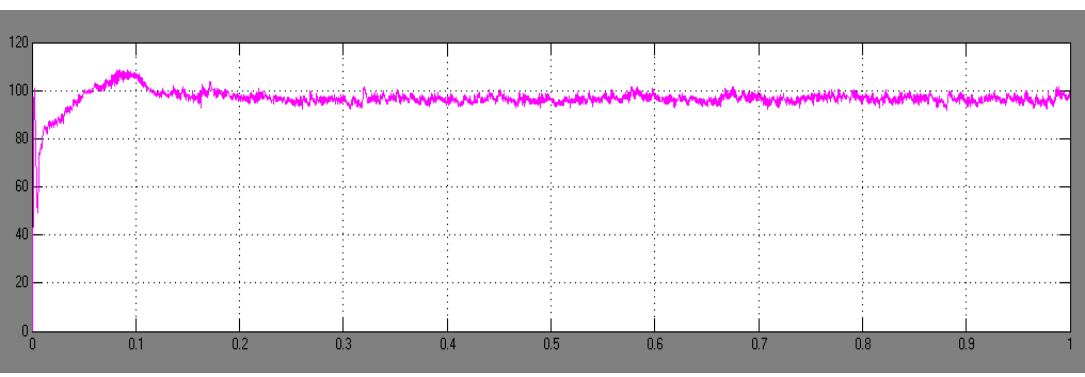

Figure 5. KY converter DC output

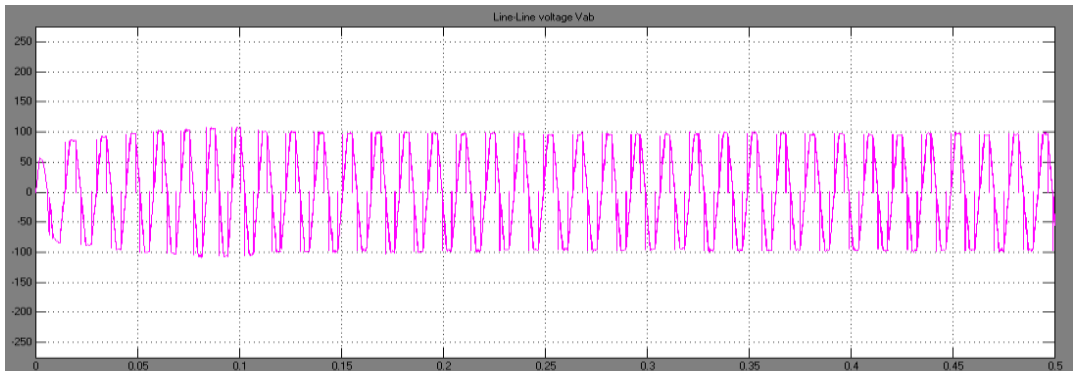

Figure 6. Inverter output

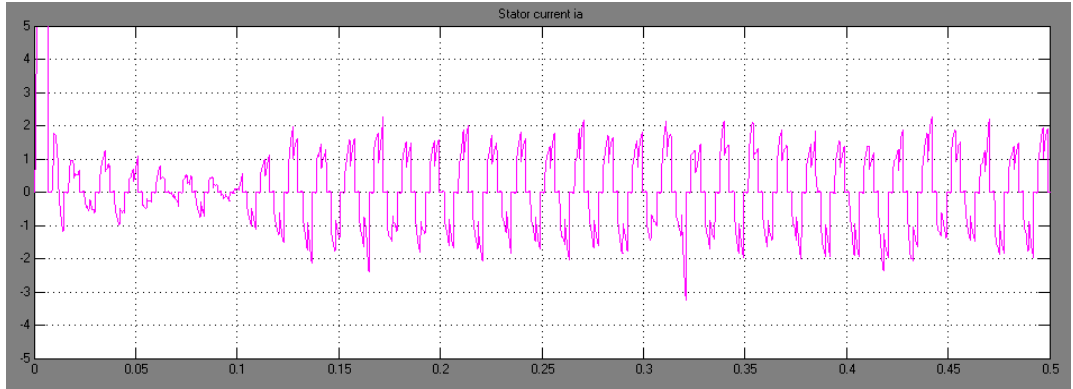

Figure 7. Stator current 


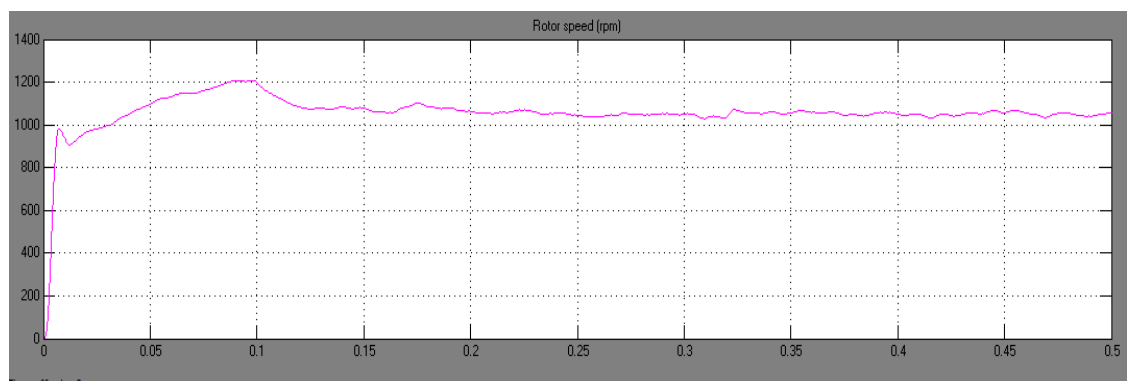

Figure 8. Motor Speed

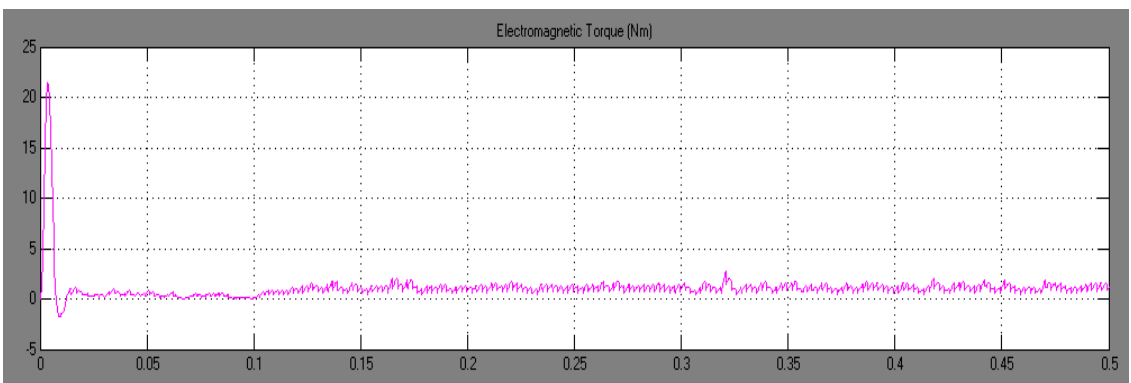

Figure 9. Torque

\section{CONCLUSION}

The operation of Brushless DC motor fed by landsman converter and KY converter is modeled in MATLAB/SIMULINK and the waveforms were observed in various operating conditions. Conventional system consists of lands converter it has more ripples and losses. It can be observed that the output power ripple of BLDC motor fed by KY converter is reduced to about $75 \%$ than that of BLDC motor fed by landsman converter. Total harmonic distortion of voltage and current at motor input is found to be $33.30 \%$. Thus by using a KY converter the output voltage ripple of the inverter circuit can be reduced and the comparison of waveforms of two circuits is done for the same input voltage and speed.

\section{REFERENCES}

[1] K I Hwu, Member, IEEE, and Y T Yau. A KY Boost Converter IEEE Transactions On Power Electronics, 2010; 25 (11).

[2] K R Sugavanam, R Senthilkumar, S Sri Krishna Kumar, S Karthikumar, V Tamilmullai. Design of FLC for OVR Reduction of Negative Output KY Converter International Journal of Applied Engineering Research. 2014; 9(24)

[3] A Vignesh Raja and S Krishna Kumar. Neuro-Fuzzy Control Based Negative Output KY Boost Converter International Conference on Engineering and Technology. 2013.

[4] Bhim Singh, Fellow, IEEE and Vashist Bist, Student Member, IEEE A BL-CSC Converter Fed BLDC Motor Drive with Power Factor Correction IEEE Transactions On Industrial Electronics

[5] R Pireethi, R Balamurugan. Department of Power Electronics and Drives, K S Rangasamy College of Technology (Autonomous) K S R Kalvi Nagar,Tiruchengode, Namakkal, Tamilnadu, India, Power Factor Correction in BLDC motor Drives Using DC-DC Converters International Conference on Computer Communication and Informatics (ICCCI -2016), 2016; 07 - 09, Coimbatore, INDIA

[6] Bavitra, K Sinthuja, S Manoharan, N and Rajesh, S The high efficiency renewable PV inverter topology. Indian Journal of Science and Technology, 2015; 8(14).

[7] Kannan, G Subramanian, D P and Shankar, R U. Reactive power optimization using firefly algorithm In Power Electronics and Renewable Energy Systems 2015; 83-90. Springer India.

[8] Sarala, P, Kodad, S. F, and Sarvesh, B. Power Factor Correction with Current Controlled Buck Converter for BLDC Motor Drive. International Journal of Power Electronics and Drive Systems (IJPEDS). 2017: 8(2).

[9] Sousa, V, Herrera, H. H, Quispe, E. C, Viego, P. R, and Gómez, J. R. Evaluation of Harmonic Distortion Generated by PWM Motor Drives in Electrical Industrial Systems. International Journal of Electrical and Computer Engineering (IJECE). 2017; 7(6).

[10] Visvanathan K, Sanjay S Chaudhary, A hybrid photovoltaic power converter system for Brushless DC Motor operation and Control. IJMSR. 2016; 8(1): 151-169. 